\title{
Association between EML4-ALK fusion gene and thymidylate synthase mRNA expression in non-small cell lung cancer tissues
}

\author{
CHUN-WEI XU ${ }^{1 *}$, GANG WANG $^{2 *}$, WU-LONG WANG ${ }^{3,4}$, WEN-BIN GAO ${ }^{2}$, CHUAN-JUN HAN ${ }^{3}$, \\ JING-SHAN GAO ${ }^{5}$, LI-YING ZHANG ${ }^{1}$, YANG LI ${ }^{6}$, LIN WANG $^{7}$, YU-PING ZHANG ${ }^{8}$, \\ YU-WANG TIAN ${ }^{1}$ and DONG-DONG $\mathrm{QI}^{2}$
}

\begin{abstract}
${ }^{1}$ Department of Pathology, The General Military Hospital of Beijing PLA, Beijing 100700; ${ }^{2}$ Department of Oncology, Affiliated Zhongshan Hospital of Dalian University, Dalian, Liaoning 116001; ${ }^{3}$ Graduate School of Dalian University, Dalian, Liaoning 116622; ${ }^{4}$ The Second Affiliated Hospital of Baotou Medical College, Baotou, Inner Mongolia 014030; ${ }^{5}$ Department of Clinical Medicine, Dalian Medical University, Dalian, Liaoning 116044; ${ }^{6}$ Department of Oncology, The General Military Hospital of Beijing PLA, Beijing 100700; ${ }^{7}$ Department of Pathology, Shanxi Dayi Hospital, Shanxi Academy of Medical Sciences, Taiyuan, Shanxi 030001; ${ }^{8}$ Department of Pathology, The People's Hospital of Weifang, Weifang, Shandong 261041, P.R. China
\end{abstract}

Received August 15, 2014; Accepted February 25, 2015

DOI: $10.3892 / \mathrm{etm} .2015 .2372$

\begin{abstract}
This study aimed to investigate the association of the mRNA expression of the echinoderm microtubule-associated protein-like 4 (EML4)-anaplastic lymphoma kinase (ALK) fusion gene with that of thymidylate synthase (TYMS) in non-small cell lung cancer (NSCLC) tissues. Quantitative polymerase chain reaction was used to detect the expression of EML4-ALK fusion gene and TYMS mRNA in 257 cases of NSCLC. The positive rate of EML4-ALK fusion gene was $4.28 \%$ in the NSCLC tissues (11/257), and was higher in nonsmokers than in smokers $(\mathrm{P}<0.05)$; TYMS mRNA expression was detected in $63.42 \%(163 / 257)$ of cases. An association of the EML4-ALK fusion gene with TYMS expression was detected; a low expression level of TYMS mRNA was observed more frequently when the EML4-ALK fusion gene was present than when it was not detected $(\mathrm{P}<0.05)$. In conclusion, patients positive for the EML4-ALK fusion gene in NSCLC tissues are likely to have a low expression level of TYMS, and may benefit from the first-line chemotherapy drug pemetrexed.
\end{abstract}

Correspondence to: Professor Wen-Bin Gao, Department of Oncology, Affiliated Zhongshan Hospital of Dalian University, 6 Jiefang Street, Zhongshan, Dalian, Liaoning 116001, P.R. China E-mail: drwenbingao@163.com

*Contributed equally

Key words: non-small cell lung cancer, EML4-ALK, thymidylate synthase, molecular detection, individual treatment

\section{Introduction}

Worldwide, lung cancer has become the cancer with the highest morbidity and mortality (1). Non-small cell lung cancer (NSCLC) accounts for 80-85\% of all cases of lung cancer (2). The echinoderm microtubule-associated protein-like 4 (EML4)-anaplastic lymphoma kinase (ALK) fusion gene was discovered in 2007 as a lung cancer-specific fusion gene in patients with lung cancer, with a positive rate of $3-8 \%$ (3). The presence of the EML4-ALK fusion gene is mutually exclusive with epidermal growth factor receptor (EGFR) mutation. The most common EML4-ALK fusion gene variants are variants 1, 2 and 3 in patients with NSCLC. The positive rates of variants 1, 2 and 3 are $\sim 33,29$ and 9\%, respectively. These three variants represent the majority of all variants; other variants are found in relatively low proportions (4-10).

The thymidylate synthase (TYMS) gene encodes the rate-limiting enzyme in the de novo synthesis of deoxythymidine monophosphate, plays an important role in DNA synthesis, replication and repair (11), leads to DNA breaks and cell death, and is an effective target for anticancer drugs. Studies have shown that TYMS activity is significantly higher than that in normal tissue in a variety of malignant tumors (12), affecting cell cycle by regulating the expression of $\mathrm{p} 53$, and thus affecting tumor cell proliferation (13). TYMS has been found to be associated with tumor proliferation (14), and tumor cell populations that overexpress TYMS have greater growth potential, suggesting that high TYMS expression correlates with poor prognosis.

For lung cancer patients with low expression levels of TYMS, the efficacy of the first-line chemotherapy drug pemetrexed (Alimta) has been demonstrated to be improved $(15,16)$. In the present multi-center study, the expression levels of the EML4-ALK fusion gene and TYMS mRNA in 257 patients with stage I-IV NSCLC were reviewed and the correlation between them was analyzed. The association of the 
EML4-ALK fusion gene with the expression of the TYMS resistance gene in patients with NSCLC was investigated in order to further explore more effective individualized treatment plans for patients carrying the EML4-ALK fusion gene.

\section{Materials and methods}

Specimens. Paraffin-embedded tissue specimens were collected from 257 patients from surgeries performed between 2004 and 2013. There were 103 cases from the General Military Hospital of Beijing PLA (Beijing, China), 58 cases from the Affiliated Zhongshan Hospital of Dalian University (Dalian, China) and 96 cases from the People's Hospital of Weifang (Weifang, China). The pathological diagnosis for the collected specimens was adenocarcinoma without preoperative chemotherapy, radiotherapy or biological immunotherapy. The specimens were analyzed for the detection of the EML4-ALK fusion gene and TYMS mRNA. All protocols were approved by the Human Clinical and Research Ethics Committees of the General Military Hospital of Beijing PLA (Beijiang, China), the Affiliated Zhongshan Hospital of Dalian University (Dalian, China) and the People's Hospital of Weifang (Weifang, China). Written informed consent was obtained from all patients.

Reagents and instruments. A DNA extraction kit (Qiagen, Hilden, Germany), RNA extraction kit (Qiagen), EML4-ALK gene expression assay kit (Amoy Diagnostics Co.,Ltd.,Xiamen, China) and TYMS Gene Expression Analysis kit (Amoy Dx Ltd.) were used. In addition, a B-500 spectrophotometer was used to measure nucleic acid protein concentrations (Shanghai Chong Meng Biotechnology Co. Ltd., Shanghai, China), and quantitative polymerase chain reaction (qPCR) assays were conducted using an ABI 7500 Real-Time PCR system (Applied Biosystems Life Technologies, Foster City, CA, USA).

\section{Methods}

qPCR detection of the EML4-ALK fusion gene. Between four and eight $4-\mu \mathrm{m}$ paraffin tissue sections were dewaxed. In accordance with the manufacturer's instructions provided with the genomic RNA extraction kit, tissue RNA was extracted and a spectrophotometer was used to detect the purity and concentration of the extracted RNA. According to the method provided with the EML4-ALK gene expression assay kit, the gene was amplified using the ABI 7500 Real-Time PCR instrument. The kit contained nine fusion mutant primers and probes to amplify the EML4-ALK gene.

qPCR detection of TYMS mRNA expression in NSCLC tissues. Tissue sections were dewaxed and tissue RNA was extracted and spectrophotometrically analyzed as described in the section above. According to the method provided with the TYMS Gene Expression Analysis kit, the gene was amplified by qPCR. An absolute quantitative method was used, with $\beta$-actin serving as a reference gene in the detection of the expression level of TYMS mRNA. The standard mean ratio of TYMS $/ \beta$-actin was $4.21 \times 10^{-3}$.

Statistical analysis. Data were analyzed using SPSS statistical analysis software, version 19.0 (SPSS, Inc., Chicago, IL, USA).

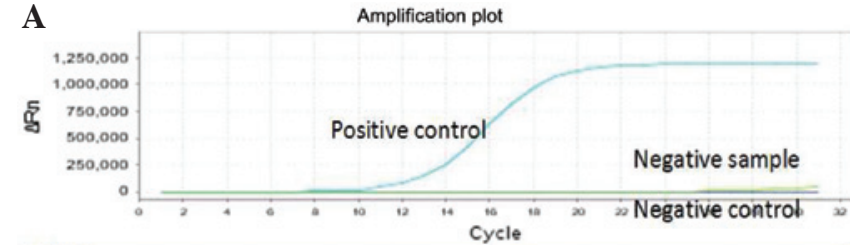

$\square=\mathrm{B} \square \mathrm{C} \square \mathrm{D} \square \mathrm{E} \square \mathrm{F} \square \mathrm{G} \square \mathrm{H}$

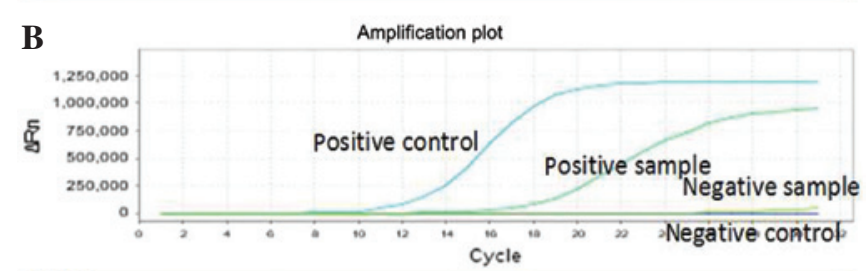

$\mathrm{A} \square \mathrm{B} \square \mathrm{C} \square \mathrm{D} \square \mathrm{E} \square \mathrm{F} \square \mathrm{G} \square \mathrm{H}$

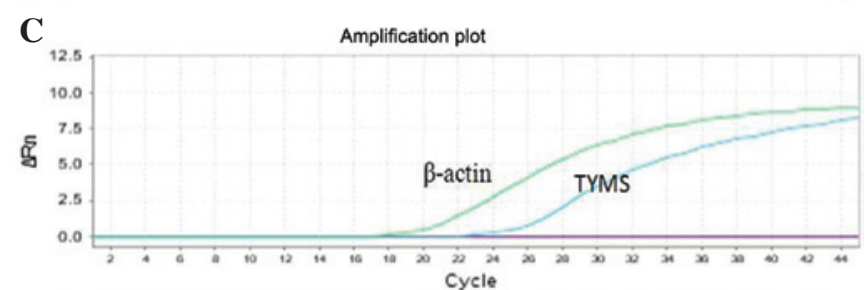

Cycle

\section{$\mathrm{A} \square \mathrm{B} \square \mathrm{C} \square \mathrm{D} \cap \mathrm{E} \square \mathrm{F} \square \mathrm{G} \square \mathrm{H}$}

Figure 1. Amplification plots for detection of the EML4-ALK fusion gene and TYMS mRNA. The EML4-ALK fusion gene's (A) positive control positive sample and negative control and (B) positive control negative sample and negative control. (C) The expression of TYMS mRNA. EML4, echinoderm microtubule-associated protein 4; ALK, anaplastic lymphoma kinase; TYMS, thymidylate synthase; Rn, normalized reporter.

Results were analyzed using $\chi^{2}$ and Fisher's exact tests, with a test level $\alpha=0.05$. The P-value was set to bilateral distribution, and $\mathrm{P}<0.05$ was considered to indicate a statistically significant difference.

\section{Results}

Correlation between EML4-ALK fusion gene and TYMS $m R N A$ expression and patient clinical characteristics. Table I shows the clinical features of the 257 cases of NSCLC, of which there were 11 cases positive for the EML4-ALK fusion gene (4.28\%). The positive rate of the EML4-ALK fusion gene was higher in non-smoking patients $(11 / 147,7.48 \% ; \mathrm{P}=0.018)$, but did not differ significantly according to patient gender, age, tumor size, lymph node metastasis or clinical stage. Of the 257 cases of NSCLC, high expression levels of TYMS mRNA were found in 163 cases $(63.42 \%)$, and low expression levels were found in 94 cases (36.58\%). The TYMS mRNA expression level did not differ significantly according to patient gender, age, smoking status, tumor size, lymph node metastasis or clinical stage, independent of other clinical features (Fig. 1A and B, Table I).

Association between the EML4-ALK fusion gene and the expression level of TYMS $m R N A$. Table II shows that 11 patients with NSCLC were EML4-ALK fusion gene-positive, 8 of 
Table I. Association between EML4-ALK fusion gene and TYMS mRNA expression and patient clinical characteristics.

\begin{tabular}{|c|c|c|c|c|c|c|}
\hline \multirow[b]{2}{*}{ Clinical features } & \multicolumn{2}{|c|}{ EML4-ALK } & \multirow[b]{2}{*}{ P-value } & \multicolumn{2}{|c|}{ TYMS } & \multirow[b]{2}{*}{ P-value } \\
\hline & Positive & Negative & & High & Low & \\
\hline Gender & & & 0.137 & & & 0.196 \\
\hline Male & 3 & 135 & & 93 & 45 & \\
\hline Female & 8 & 111 & & 70 & 49 & \\
\hline Age (years) & & & 0.520 & & & 0.907 \\
\hline$\geq 59$ & 4 & 126 & & 82 & 48 & \\
\hline$<59$ & 7 & 120 & & 81 & 46 & \\
\hline Smoking history & & & 0.018 & & & 0.166 \\
\hline Yes & 0 & 99 & & 68 & 31 & \\
\hline No & 11 & 147 & & 95 & 63 & \\
\hline Tumor diameter $/ \mathrm{cm}$ & & & 0.637 & & & 0.798 \\
\hline$\geq 5$ & 4 & 119 & & 79 & 44 & \\
\hline$<5$ & 7 & 127 & & 84 & 50 & \\
\hline Node metastasis & & & 0.751 & & & 0.627 \\
\hline Yes & 5 & 100 & & 70 & 35 & \\
\hline No & 6 & 146 & & 93 & 53 & \\
\hline Clinical stage & & & 0.495 & & & 0.524 \\
\hline I & 5 & 87 & & 56 & 36 & \\
\hline $\mathrm{II}+\mathrm{III}+\mathrm{IV}$ & 6 & 159 & & 107 & 58 & \\
\hline
\end{tabular}

EML4, echinoderm microtubule-associated protein 4; ALK, anaplastic lymphoma kinase; TYMS, thymidylate synthase.

Table II. Association between the EML4-ALK fusion gene and the expression level of TYMS mRNA.

\begin{tabular}{lrrr}
\hline & \multicolumn{2}{c}{$\begin{array}{c}\text { Expression of } \\
\text { TYMS mRNA }\end{array}$} & \\
\cline { 2 - 3 } EML4-ALK fusion gene & High & Low & Total \\
\hline Positive & 3 & 8 & 11 \\
Negative & 160 & 86 & 246 \\
Total & 163 & 94 & 257 \\
\hline
\end{tabular}

EML4, echinoderm microtubule-associated protein 4; ALK, anaplastic lymphoma kinase; TYMS, thymidylate synthase.

whom had low levels of TYMS mRNA expression (72.73\%). Of the 246 patients with NSCLC that were EML4-ALK fusion gene-negative, low expression levels of TYMS mRNA were found in 86 cases (34.96\%). Patients with NSCLC that were EML4-ALK fusion gene-positive tended to have lower expression levels of TYMS mRNA than those who were negative (72.73 vs. $34.96 \%$, P<0.05; Fig. 1C, Table II).

\section{Discussion}

The EML4-ALK fusion gene is selectively inhibited by crizotinib (also known as g azole imatinib or Sai Rui ${ }^{\mathrm{TM}}$ ). When crizotinib was clinically tested in patients with NSCLC, phase I and II clinical trials obtained good results and no adverse reactions, and patients that tolerated the treatment entered phase III clinical trials (17-19). In 2010, Choi et al (20) reported one case of an EML4-ALK-positive patient with NSCLC who after 5 months of treatment with crizotinib developed resistance to the drug; two types of point mutation were identified: C1156Y and L1196M. Therefore, further exploration of an individualized treatment plan for certain patients with primary or secondary resistance to crizotinib is of great practical value and practical significance.

The results of the present study show that in the patients with stage I-IV NSCLC, the positive rate of the EML4-ALK fusion gene was $4.28 \%(11 / 257)$ and was higher in nonsmokers than in smokers $(\mathrm{P}<0.05)$. This positive rate is slightly lower than that in four other studies, in which the EML4-ALK fusion gene positive rate was from 4.69\%(3/64) to $11.65 \%(12 / 103)(7,21-23)$. High expression levels of TYMS were exhibited in the NSCLC tissues at a rate of $63.42 \%$ $(163 / 257)$, and the results are similar to those reported by Gandara et al (24). The TYMS expression levels were found not to differ according to patient gender, age, smoking status, tumor size, lymph node metastasis, pathological stage or other clinical characteristics.

The present study observed that in NSCLC patients, the EML4-ALK fusion gene has an association with the expression level of TYMS $(\mathrm{P}<0.05)$, as a majority of the EML4-ALK fusion gene-positive patients had low expression levels of TYMS. The development of resistance to chemotherapy is one of the main causes of tumor treatment failure. Following the 
short-term application of pemetrexed chemotherapy, TYMS induction may occur, leading to TYMS overexpression, increased catalytic activity and the resistance of tumor cells. High expression levels of TYMS enhance the DNA synthesis and repair capacity of proliferating cells, making the lung cancer cells less susceptible to being killed by chemotherapy drugs and leading to drug resistance; when there is a low expression level of TYMS, the development of pemetrexed resistance does not occur so readily, which increases the likelihood of effective chemotherapy. This may be a theoretical basis for the mechanism underlying the observation that EML4-ALK fusion gene-positive NSCLC patients have a higher response rate to chemotherapy.

In summary, this study initially identified that patients with NSCLC who are EML4-ALK fusion gene-positive tend to have low expression levels of TYMS, and it is speculated that EML4-ALK fusion gene-positive patients will have greater responsiveness to pemetrexed chemotherapy; however, the inherent molecular mechanisms underlying this phenomenon require further study. Our group mainly studies the association between the chemotherapy drugs cisplatin and gemcitabine, drug resistance genes and the EML4-ALK fusion gene. In the present study, we examined the association between the pemetrexed resistance gene TYMS and the EML4-ALK fusion gene, but did not consider the microtubule drug resistance gene TUBB3 in first-line chemotherapy. Future studies will examine the association between the EML4-ALK fusion gene and TUBB3 to further explore more effective individualized treatment plans. In particular, research will focus on individualized treatment plans for patients with primary or secondary resistance to the EML4-ALK fusion gene-selective inhibitor crizotinib.

\section{Acknowledgements}

This study was supported by a grant from the Wu Jieping Medical Foundation Clinical Research Special Fund (no. 320.6750.1360).

\section{References}

1. Jemal A, Bray F, Center MM, Ferlay J, Ward E and Forman D: Global cancer statistics. CA Cancer J Clin 61: 69-90, 2011.

2. Sher T, Dy GK and Adjei AA: Small cell lung cancer. Mayo Clin Proc 83: 355-367, 2008

3. Horn L and Pao W: EML4-ALK: Honing in on a new target in non-small-cell lung cancer. J Clin Oncol 27: 4232-4235, 2009.

4. Soda M, Choi YL, Enomoto M, Takada S, Yamashita Y, Ishikawa S, Fujiwara S, Watanabe H, Kurashina K, Hatanaka $\mathrm{H}$, et al: Identification of the transforming EML4-ALK fusion gene in non-small-cell lung cancer. Nature 448: 561-566, 2007.

5. Inamura K, Takeuchi K, Togashi Y, Nomura K, Ninomiya $H$, Okui M, Satoh Y, Okumura S, Nakagawa K, Soda M, et al: EML4-ALK fusion is linked to histological characteristics in a subset of lung cancers. J Thorac Oncol 3: 13-17, 2008.

6. Perner S, Wagner PL, Demichelis F, Mehra R, Lafargue CJ, Moss BJ, Arbogast S, Soltermann A, Weder W, Giordano TJ, et al: EML4-ALK fusion lung cancer: A rare acquired event. Neoplasia 10: 298-302, 2008
7. Wong DW, Leung EL, So KK, Tam IY, Sihoe AD, Cheng LC, Ho KK, Au JS, Chung LP and Pik Wong M; University of Hong Kong Lung Cancer Study Group: The EML4-ALK fusion gene is involved in various histologic types of lung cancers from nonsmokers with wild-type EGFR and KRAS. Cancer 115: 1723-1733, 2009.

8. Shaw AT, Yeap BY, Mino-Kenudson M, Digumarthy SR, Costa DB, Heist RS, Solomon B, Stubbs H, Admane S, McDermott U, et al: Clinical features and outcome of patients with non-small-cell lung cancer who harbor EML4-ALK. J Clin Oncol 27: 4247-4253, 2009.

9. Martelli MP, Sozzi G, Hernandez L, Pettirossi V, Navarro A, Conte D, Gasparini P, Perrone F, Modena P, Pastorino U, et al: EML4-ALK rearrangement in non-small cell lung cancer and non-tumor lung tissues. Am J Pathol 174: 661-670, 2009.

10. Sasaki T, Rodig SJ, Chirieac LR and Jänne PA: The biology and treatment of EML4-ALK non-small cell lung cancer. Eur J Cancer 46: 1773-1780, 2010.

11. Diasio RB and Johnson MR: The role of pharmacogenetics and pharmacogenomics in cancer chemotherapy with 5-fluorouracil. Pharmacology 61: 199-203, 2000.

12. Fukushima M, Morita M, Ikeda K and Nagayama S: Population study of expression of thymidylate synthase and dihydropyrimidine dehydrogenase in patients with solid tumors. Int J Mol Med 12: 839-844,2003.

13. Chu E, Copur SM, Ju J, Chen TM, Khleif S, Voeller DM, Mizunuma N, Patel M, Maley GF, Maley F and Allegra CJ: Thymidylate synthase protein and p53 mRNA form an in vivo ribonucleoprotein complex. Mol Cell Biol 19: 1582-1594, 1999.

14. Kawakami K, Graziano F, Watanabe G, Ruzzo A, Santini D, Catalano V, Bisonni R, Arduini F, Bearzi I, Cascinu S, et al: Prognostic role of thymidylate synthase polymorphisms in gastric cancer patients treated with surgery and adjuvant chemotherapy. Clin Cancer Res 11: 3778-3783, 2005.

15. Righi L, Papotti MG, Ceppi P, Billè A, Bacillo E, Molinaro L, Ruffini E, Scagliotti GV and Selvaggi G: Thymidylate synthase but not excision repair cross-complementation group 1 tumor expression predicts outcome in patients with malignant pleural mesothelioma treated with pemetrexed-based chemotherapy. J Clin Oncol 28: 1534-1539, 2010.

16. Gomez HL, Santillana SL, Vallejos CS, Velarde R, Sanchez J, Wang X, Bauer NL, Hockett RD, Chen VJ, Niyikiza C and Hanauske AR: A phase II trial of pemetrexed in advanced breast cancer: Clinical response and association with molecular target expression. Clin Cancer Res 12: 832-838, 2006.

17. Kwak EL, Bang YJ, Camidge DR, et al: Anaplastic lymphoma kinase inhibition in non-small-cell lung cancer. N Engl J Med 363: 1693-1703, 2010.

18. Kim DW, Ahn MJ, Shi YK, et al: Updated results of a global phase II study with crizotinib in advanced ALK-positive non-small cell lung cancer (NSCLC). J Clin Oncol 30 (Suppl): abstr 7533, 2012.

19. Shaw AT, Kim DW, Nakagawa K, et al: Crizotinib versus chemotherapy in advanced ALK-positive lung cancer. N Engl J Med 368: 2385-2394, 2013.

20. Choi YL, Soda M, Yamashita Y,Ueno T, Takashima J, Nakajima T, Yatabe Y, Takeuchi K, Hamada T, Haruta H, et al; ALK Lung Cancer Study Group: EML4-ALK mutations in lung cancer that confer resistance to ALK inhibitors. N Engl J Med 363: 1734-1739, 2010.

21. Rikova K, Guo A, Zeng Q, Possemato A, Yu J, Haack H, Nardone J, Lee K, Reeves C, Li Y, et al: Global survey of phosphotyrosine signaling identifies oncogenic kinases in lung cancer. Cell 131: 1190-1203, 2007.

22. Zhang X, Zhang S, Yang X, Yang J, Zhou Q, Yin L, An S, Lin J, Chen S, Xie Z, et al: Fusion of EML4 and ALK is associated with development of lung adenocarcinomas lacking EGFR and KRAS mutations and is correlated with ALK expression. Mol Cancer 9: 188, 2010.

23. Sun Y, Ren Y, Fang Z, Li C, Fang R, Gao B, Han X, Tian W, Pao W, Chen $\mathrm{H}$ and Ji H: Lung adenocarcinoma from East Asian never-smokers is a disease largely defined by targetable oncogenic mutant kinases. J Clin Oncol 28: 4616-4620, 2010.

24. Gandara DR, Huang E and Desai S: Thymidylate synthase (TS) gene expression in patients with ALK positive(+) non-small cell lung cancer (NSCLC): Implications for therapy. J Clin Oncol 30 (Suppl): a7582, 2012. 